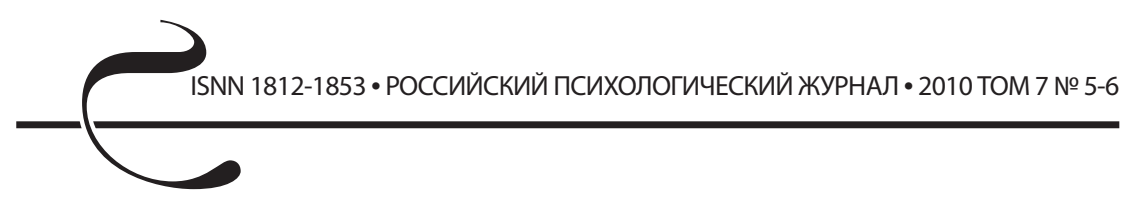

Дикая Л.А.

\title{
Обратная сторона креативности. \\ Роль креативности в противодействии терроризму
}

В работе рассматривается проблема антисоииального и криминального использования творческих способностей, анализируются психологические аспекты использования террористами нестандартных приёмов при осуществлении террористических актов, а также возможности использования творческих подходов и тактик противодействия терроризму. Предлагаются направления для изучения негативного сочиального проявления креативности, для разработки креативного подхода при создании концепиий и практических методов эффективного противодействия террористическим угрозам.

Ключевые слова: креативность, противодействие терроризму, методы обнаружения лжи.

Исследования творчества в основном сосредоточены на положительных сторонах этого явления, в то время как его обратная «тёмная» сторона в значительной степени игнорируется. Между тем эта сторона касается не только творческого потенциала, преднамеренно направленного на причинение вреда другим, например мошенничество, тяжкие уголовные преступления, в том числе терроризм, но и случайного отрицательного непроизвольного его влияния при совершении поступков с благими намерениями [17].

Хотя креативность как способность к созданию нового часто связывается исследователями с самореализацией личности, и их внимание акцентируется на её внутреннем аспекте, следует признать, что внешнее влияние творчества на социальные процессы может быть достаточно сильным. Традиционно представление о том, что творчество должно быть конструктивным и социально одобряемым, а развитие творческого потенциала, таким образом, является социально желательным. Однако те, кто желает причинить преднамеренный вред другим, используют свой творческий потенциал со злым умыслом, прибегая к тем же способам и закономерностям создания новой идеи, как и при конструктивном творчестве.

В современных научных исследованиях показано, что криминальные «способности» многих преступников, независимо от их пола и возраста, взаимосвязаны с высоким уровнем развития у них творческого потенциала. Например, мошенники отличаются не только развитыми интеллектуальными качествами - сообразительностью, осмотрительностью, изворотливостью, хитростью ума и т.д., но творческим характером мышления и поведения; они динамичны, их действия постоянно меняются и обновляются [16; 19].

Обратная сторона креативности не остается без внимания террористических группировок. Так, лидеры террористической группировки «Аль-Каида» в Саудовской Аравии акцентируют внимание на психологическом эффекте от «асимметричной» 
войны с использованием нетрадиционной тактики боевых действий, новых видов оружия и технологий, которые предполагают нестандартное мышление и фантазию, чтобы перехватить инициативу и получить свободу действий [по 8].

Независимая комиссия Конгресса США, расследующая причины терактов 11 сентября 2001 года в своём отчёте использовала термин «новый тип террористических угроз», отмечая особый, нестандартный подход террористов к проведению своих преступных действий. Нестандартность этого подхода заключается в применении методов, не укладывающихся в систему противодействия террору спецслужб США. Террористы как бы ищут брешь в этой системе противодействия и наносят удар в самое уязвимое место [14].

Г.Н. Трошев, анализируя опыт проведения антитеррористических операций в Дагестане и Чечне, отмечает, что боевики часто использовали нестандартные приемы и тактику боя при захвате ключевых выгодных позиций и маскировке своих огневых средств, при минировании местности. Террористы применяют тактику активных боевых действий небольшими группами, ведение снайперами стрельбы под звуковым прикрытием минометных и гранатометных выстрелов, нестандартную тактику организации засад и инженерного оборудования боевых позиций, использование радиообмена с целью дезинформации и т.п. [15]. В докладе Госдепартамента в Конгрессе США «Тенденции терроризма: 2006» отмечается высокая креативность террористов, как в вопросах проведения нападений и пропаганды, так и в вопросах финансового обеспечения своих акций [по 5].

Вышеприведенные примеры позволяют заключить, что изучение психологических механизмов этой обратной «тёмной» стороны креативности позволит проникнуть в суть действий и мышления террористов, понять их потенциальные планы, идеи и выработать такие же креативные решения по противодействию терроризму.

В ряде исследований приводятся доводы в пользу ценности использования творческого потенциала для предотвращения террористических актов $[2,17$, $19,20]$. Трудности, связанные с обострениями международной напряженности, в том числе и из-за террористических угроз, во многом обусловлены тем, что не используются творческие возможности решения этих проблем. Креативный подход к прогнозированию, предупреждению и предотвращению потенциальных нестандартных террористических угроз может стать отправной точкой для более детального исследования [21].

Так, Cropley et al., рассматривая ключевые идеи креативности аисоциальной направленности, выделяет ряд принципов, анализ которых может помочь в развитии более эффективных средств противодействия терроризму.

1. Проявление креативности в действиях людей с антиобщественными намерениями не зависит от одобрения их целей окружающими.

2. Творческий потенциал, как с «добрым», так и со «злым» умыслом, является конкурентоспособным рычагом для обхода людьми правил и законов общества. Его использование может принести выгоду всем, кому он доступен. 
3. Террористические и антитеррористические решения необходимо анализировать по четырем основным параметрам креативного продукта: эффективность, новизна, оригинальность и простота (вседоступность).

4. Чем решение более креативное (т.е. более новое, оригинальное и простое), тем оно более эффективно.

5. Чем более новое решение, тем меньше эффективность стандартных решений по противодействию ему.

6. Новизна решений уменьшается с течением времени.

7. Раскрытие сущности решения ускоряет снижение его новизны.

8. Снижение новизны решений вызывает снижение их эффективности.

9. Творческое противодействие террористическим решениям будет ускорять снижение их новизны и эффективности.

10.Незамедлительные упреждающие антитеррористические решения - это также творческие решения.

11.Высококреативные упреждающие антитеррористические решения должны быть тщательно продуманы и подготовлены [17].

Необходимость новых нестандартных подходов и решений для противодействия терроризму очевидна. Тем не менее, во многих странах методы и тактика антитеррористических действий регламентируются на законодательном уровне, что во многом ограничивает рамки использования новых нестандартных решений по противодействию терроризму. А особенности борьбы с терроризмом требуют сочетания самых современных и разнообразных средств, методов противодействия, различных навыков и технического оснащения, умений оперативно планировать действия и принимать нестандартные решения в быстро меняющейся обстановке. Для расширения креативного поля при разработке антитеррористических решений возникает необходимость введения особых поправок в законодательство, расширяющих полномочия силовых органов в борьбе с терроризмом, и позволяющих использовать более эффективные инструменты противодействия террористической деятельности.

Несомненно, проблема творческого, нестандартного мышления является важной при создании и подготовке специальных антитеррористических подразделений особого назначения. Необходимость в создании небольших, но всесторонне подготовленных отрядов спецназа для проведения нестандартных операций, бойцы которых отличаются высокой сплоченностью и дисциплиной, творческим подходом к решению разного рода боевых задач и обладают способностями самостоятельно решать возникающие проблемы в любых условиях, возникла задолго до появления массовых террористических угроз. Во многих спецслужбах при отборе и подготовке сотрудников большое внимание уделяется их творческим способностям. Так, например, процедура отбора кадров для работы в израильской разведке включает задания, требующие нестандартного мышления и быстрой реакции [10]. Анализируя систему подготовки офицеров подразделений специального назначения, С.В. Козлов отмечает, что главное внимание уделяется 
воспитанию у курсантов боевого духа, а также умения мыслить дерзко и нестандартно [6]. О.Е. Рязанов, рассматривая особенности подготовки и использования снайперов в боевых действиях, пишет о том, что умение нестандартно мыслить является одним из основных профессиональных качеств снайпера, позволяющих выполнить задачу и выжить. В ряде иностранных армий при подготовке снайперов спецподразделений инструкторы вынуждены искусственно устранять «командный инстинкт», чтобы стрелки научились сами думать о себе, стимулируют придание индивидуальных черт оружию и средствам маскировки, одновременно решая задачу по составлению постоянных пар (стрелок и корректировщик), образующих предельно сплоченный мини-коллектив [12]. Несомненно, в ближайшие годы перспективными станут универсальные бойцы, способные ориентироваться и вести бой в нестандартных ситуациях.

Использование творческого подхода становится ценным при разработке принципиально новых методов обнаружения террористов, методик расследования террористических актов, новых подходов при взрывотехнической диагностике, криминалистической идентификации личности, при оценке диверсионнотеррористической уязвимости гражданских объектов, методов получения информации об источниках и характере террористических угроз и разработке мер по их предупреждению $[1,7,13]$. Так, использование метода детекции лжи с помощью полиграфа позволяет в течение трёх часов с высокой достоверностью выявить лиц, причастных к исполнению и планированию теракта, определить состав и роли членов террористической группы, выяснить детали, тактику и механизм совершения теракта $[4,9]$. На практике получили поддержку и новейшие методы оценки причастности к терроризму авиапассажиров, которые включают в себя возможности предполетного психотестирования («профайлинг») - это установленные в крупных аэропортах антирисковые терминалы MindReader и SSRM Tek, имеющие высокую пропускную способность и кросскультурную адаптивность за счет использования стимулов-изображений [11].

В связи с вышеизложенным актуальной становится задача разработки психологических практических программ развития креативности как интегрального свойства личности, психологических тренингов развития творческого мышления и поведения для сотрудников антитеррористических подразделений. Изучение психологических, психофизиологических и нейрофизиологических механизмов творческой активности поможет создать надежную научную основу для разработки программ тренингов с биологической обратной связью оптимального для творческого процесса функционального состояния коры головного мозга $[3,18]$.

Таким образом, изучение природы «обратной» стороны креативности и её негативного социального воздействия может не только способствовать выявлению и пониманию механизмов возникновения этого явления, но также позволит разработать концепции и практические методы эффективного противодействия самым изощрённым и нестандартным тактикам запугивания людей террористами, предотвращения террористических угроз. 


\section{Литература}

1. Артамонов И.И. Терроризм: способы предотвращения, методика расследования. Монография. - М.: Изд-ль Шумилова И.И., 2002. - 297 с.

2. Дикая Л.А. Конференция «Противодействие идеологии экстремизма и терроризма в рамках реализации государственной молодежной политики» // Российский психологический журнал. - 2009. - Т. 6. - № 4. - С. 29-35.

3. Дикая Л.А. Современная психофизиология и мозговые механизмы творчества // Российский психологический журнал. - 2008. - Т. 5. - № 4. - С. 6570.

4. Дикий И.С. Информативные признаки инструментальной детекции скрываемой информации у лиц с различными особенностями межполушарной функциональной асимметрии мозга // Российский психологический журнал. - 2009. T. 6. - № 2. - С. 43-46.

5. Коган А. Террор высокой креативности // Еврейский мир (Газета русскоязычной Америки). - 19.08.2006.

6. Козлов С.В. Спецназ ГРУ. Пятьдесят лет истории, двадцать лет войны: сб. статей. - М.: Русская панорама, 2003. - 600 с.

7. Моторный И.Д. Современный терроризм и оценка диверсионнотеррористической уязвимости гражданских объектов: монография. - М.: Издво Шумилова И.И., 2004. - 106 с.

8. Нечитайло Д.А. Асимметричная война» исламистов // Независимая газета / Политика. - 05.08.2009.

9. Николаева И.Н. Опыт использования полиграфа при расследовании резонансных преступлений // Российский полиграф. - Вып. 1. - 2008.

10. Островский В.П. Обратная сторона обмана (Скрытые операции Моссад) - Харьков: Свитовид, 2004. - 320 с.

11. Подосинов В.Н. Профайлинг в системе предполетного досмотра / Материалы VII международной научной конференции «Наука и образование». - Кемерово: Кемеровский государственный университет, 2008.

12. Рязанов О.Е. История снайперского искусства // Братишка. - М., 2004.

13. Сафонов И.И. Организация раскрытия и расследования терроризма: моногография. - М.: Изд-во Шумилова И.И., 2004. - 132 с.

14. Соколов В. Буш Америке не нужен? Конгресс помешает нынешнему американскому президенту избраться на второй срок // НОМАД - 26.03.2004.

15. Трошев Г.Н. Моя война. Чеченский дневник окопного генерала. - М.: Вагриус, 2001. - 382 c.

16. Фойницкий И.Я. Мошенничество по русскому праву: в 2-х ч. Ч. 1. - М.: Изд-во СГУ, 2006. - С. 9.

17. Cropley D.H., Kaufman J., Cropley A.J. and Runco M.A. The Dark Side of Creativity, Cambridge University Press. - 2010.

18. Dikaya L.A., Ermakov P.N. Peculiarities of frequency-spatial organization of brain cortical bio-potentials in creative individuals performing divergent and convergent tasks // International journal of psychophysiology. - 2010. - V. 77. - № 3. - P. 316-317. 
19. Eisenman R. Creativity, Mental Illness and Crime. Dubuque, IA: Kendall / Hunt Publishing Company. - 2007. - $139 \mathrm{p}$.

20. James K., Drown D. Whether "Malevolent" or "Negative," Creativity is Relevant to Terrorism Prevention: Lessons From 9/11 And Hazardous-Material Trucking. Creativity Research Journal. - 2008. - 20. - P. 120-128.

21. James K. Creative anti-terrorism strategies: Promoting collective efficacy for hazardous material trucking terrorism prevention // Journal of Occupational Health Psychology. - 2008. - 13. - P. 24-31. 